\title{
DETERMINING SLOPED-LOAD LIMITS INSIDE VON MISES TRUSS WITH ELASTIC SUPPORT
}

\author{
DOLOČEVANJE MEJ NAGNJENE OBREMENITVE ZNOTRAJ VON \\ MISESOVEGA PALIČJA Z ELASTIČNO PODPORO
}

\author{
Sergiy Bilyk, Vitaliy Tonkacheiev \\ Kyiv National University of Civil Engineering and Architecture, Department of Steel and Wooden Structures, \\ Povitroflotskyi Ave. 31, 49600 Kyiv, Ukraine \\ vartist@ukr.net, thetvg@gmail.com
}

Prejem rokopisa - received: 2016-05-11; sprejem za objavo - accepted for publication: 2017-10-26

\author{
doi:10.17222/mit.2016.083
}

\begin{abstract}
The scientific novelty of this work lies in the description of the methods of calculating and analyzing the symmetrical stability loss of the von Mises truss in the case of sloped loads with an elastic support at the top of the truss. In this work, we consider a deformed layout of the von Mises truss with an elastic support under a concentrated load at the apex joint about the vertical axis. Numerical studies were carried out using the proposed methods. This work indicates the impact of the sloped load and elastic support on the truss' stability loss. We determined dependencies of critical external-load values on the rod's starting pitch for different situations. For each design situation, we obtained generalized expressions for determining critical force values for the truss' apex joint. We obtained dependencies and analytical expressions for determining the critical load on the dome structure, based on the initial geometrical parameters, taking into account the reaction of the elastic support at the apex joint and the direction of the external loads. Our studies show that increasing the support's stiffness increases the sustainability of the von Mises truss. Additionally, we obtained new results required for improving the stability of trusses under a sloped load with an angle of $10-40^{\circ}$ about the vertical axis.
\end{abstract}

Keywords: von Mises truss, elastic support, sloped load on joints, buckling, steel dome

Pričujoči članek predstavlja nov znanstveni prispevek za opis metode izračuna in analize izgube simetrične stabilnosti von Misesovega paličja v primeru nagnjenega bremena $\mathrm{z}$ elastičnimi podporami na vrhu paličja. V članku avtorja obravnavata potek deformacije von Misesovega paličja z elastično podporo pod koncentrirano obremenitvijo na vrhu vezi okoli vertikalne osi. $\mathrm{S}$ predlaganimi metodami sta avtorja izvedla numerične študije. V prispevku predstavita vpliv nagiba bremena in elastične podpore na izgubo stabilnosti paličja. Ugotovila sta, kakšen je vpliv kritične zunanje obremenitve na začetni položaj paličja pri različnih pogojih izračunanvanja. Za vsako izbrano situacijo sta avtorja dobila generaliziran izraz za določitev vrednosti kritične sile v vrhu vezi paličja. Ugotovila sta, kakšne so odvisnosti in dobila analitične izraze za kritično obremenitev kupolaste strukture na osnovi začetnih geometrijskih parametrov, upoštevajoč reakcijo elastične podpore na vrhu vezi in smer zunanje obremenitve. Studija je pokazala, da naraščajoča togost podpore povečuje nosilnost von Misesovega paličja. Dodatno sta avtorja prispevka dobila nove rezultate za izboljšanje stabilnosti paličja pod kotom od $10^{\circ}$ do $40^{\circ}$ nagnjeno obremenitvijo okoli vertikalne osi.

Ključne besede: von Misesovo paličje, elastična podpora, nagnjena obremenitev vezi, uklon, jeklena kupola

\section{INTRODUCTION}

Dome structures are highly applicable due to a number of positive characteristics, including the following: possibility to cover large amounts of space with a minimum surface area, which in turn leads to reduced expenses of the thermal energy for heating; a low material consumption in comparison with other covering designs; no need for intermediate supports; architectural expressiveness; the ability to use small identical elements and typical joint connections. Another positive feature of a dome is a pretty good maintainability, achieved due to the possibility to replace individual parts without the dome structure losing its carrying capacity as a whole. ${ }^{1}$

Recent building practice pays most of the attention to the use of efficient design solutions. One of the ways to increase the efficiency of the building production is the use of light spatial covering structures, including shells and domes.
There are the following types of steel dome structures characterized by special design features: reticulated structures, ribbed, ribbed-ring and ribbed-ring structures with connections. Despite the minimal material consumption, the characteristic of reticulated domes - the complexity of the joint connections - is an important factor, which affects the carrying capacity and the cost. For small $(12-30 \mathrm{~m})$ spans, it is cost-effective to use plain ribbed domes that require a similar material consumption as the reticulated ones under the same conditions.

Hinge joints are traditionally used for the ribbeddome designs. The biggest problem of the hinge-joint design is the buckling of the apex joint and the elements adjacent to it. It is considered conventional to use a three-hinged arch as the design model for a ribbed dome. ${ }^{2}$ The dependence between the dome load and displacement of the arch's apex joint is nonlinear. ${ }^{3,4,5}$ 
Deformation of such a system is usually analyzed using three-hinged rod-system models.

The first study of a three-hinged rod system was conducted by R. V. Mises ${ }^{6}$ and the systems themselves are called von Mises trusses. We conducted a wide range of studies, taking into account the elastic reactions of the system and elastic supports at the joints, ${ }^{7,8}$ getting close to that of Zeman's machines. ${ }^{9}$ There are researches of Stoker's column buckling. ${ }^{10}$ There are thorough researches of the von Mises truss buckling based on dynamic criteria for the elastic supports. ${ }^{7,11}$ The basic research of the von Mises truss buckling under a vertical symmetrical load and a possible symmetric or asymmetric stability loss is reported in references..$^{9,12,13}$ Also, there are researches using the finite-element analysis for non-linear structures. ${ }^{14,15,16}$

Earlier studies are insufficient in terms of their use when determining the buckling of more complex systems such as ribbed domes with rings. The top of a dome model can be considered as a model consisting of the von Mises truss combination. However, we must consider the impact of the adjacent elements. The impact of the adjacent elements on the truss' apex joint ought to be modeled as an additional elastic support, and exactly that was done in this study. At the same time, the structure of a dome can have a dedicated element of the von Mises truss under a sloped load. The impact of circular dome elements can be modeled in the form of additional elastic supports at dome's joints.

These studies are based on generalized characteristics of the von Mises truss buckling under a sloped load, obtained with the research from reference. ${ }^{17}$

\section{STATEMENT OF THE PROBLEM}

The purpose of this study is to determine the dependencies of the maximum values of the relative force at an apex joint, at which the joint starts loosing its stability, on the initial pitch of the rods in the system with different input parameters of a design scheme. A deformed scheme of the von Mises truss with an elastic support and a sloped load at the apex joint of the truss is presented on Figure 1.

The methods of research are described in reference ${ }^{17}$ and implemented with the algorithm from Figure 2.

For convenience of the implementation of numerical studies, a generalized stability criterion ${ }^{17}$ is presented in the parametric form:

$$
\frac{P \cdot \cos \beta_{\mathrm{p}}}{E \cdot A_{\mathrm{cal}}}=A+B+C+D
$$

where $A=\frac{v_{\mathrm{p}} \cdot k_{v}}{E \cdot A_{\text {cal }}} \cdot \frac{a_{0}}{a_{0}}$

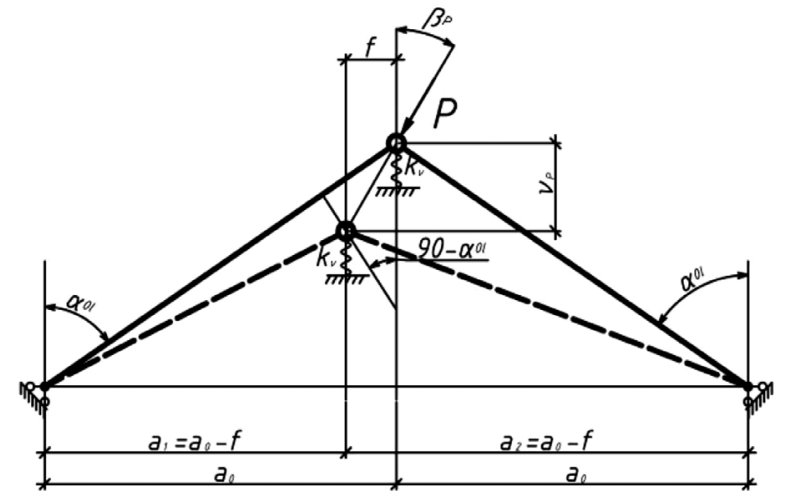

Figure 1: Deformed scheme of the von Mises truss with an inclined load and elastic support at the apex joint of the truss where: $\alpha_{01}-$ initial rod slope about the vertical axis; $a_{0}$ - half part of truss span; $\beta_{\mathrm{p}}$ - force pitch at the apex joint about the vertical axis; $k_{v}$ - elastic support stiffness parameter for the apex joint; $P$ - sloped load

$$
\begin{aligned}
& B=\frac{\frac{1}{\tan \alpha_{01}}-\frac{v_{\mathrm{p}}}{a_{0}}}{\sqrt{\left(1-\frac{v_{\mathrm{p}}}{a_{0}} \cdot \tan \beta_{\mathrm{p}}\right)^{2}+\left(\frac{1}{\tan \alpha_{01}}-\frac{v_{\mathrm{p}}}{a_{0}}\right)^{2}}} \\
& C=\frac{\sqrt{\left(1+\frac{v_{\mathrm{p}}}{a_{0}} \cdot \tan \beta_{\mathrm{p}}\right)^{2}}+\left(\frac{v_{\mathrm{p}}}{\tan \alpha_{01}}-\frac{1}{a_{0}}\right.}{\left.\sqrt{\tan \alpha_{01}}-\frac{v_{\mathrm{p}}}{a_{0}}\right)^{2}} \\
& D=-2 \sin \alpha_{01} \cdot\left(\frac{1}{\tan \alpha_{01}}-\frac{v_{\mathrm{p}}}{a_{0}}\right)
\end{aligned}
$$

- parameters of Equation (1).

The maximum values for the relative joint load of the apex joint, at which the truss starts to lose stability, are defined for the value range of the initial rod pitch about the vertical axis of $45-89^{\circ}$ using the "golden section" method. ${ }^{18}$

We selected a segment from $v_{\mathrm{p}} / a_{0}=0$ to the relative displacement value, at which the first derivative of generalized stability criterion function (1) changes its sign to the opposite as the criterion for determining the initial range for searching extremes.

\section{RESULTS AND DISCUSSION}

Some results of the numerical studies are presented in Figure 3. When increasing the force pitch about the vertical axis, the maximum relative force increases, and its procession slows down somewhat, but upon reaching the maximum relative force, the loss of the joint stability takes place faster than at the low pitch (Figure 3a).

The presence of the elastic support at the apex joint in the absence of a sloped load leads to an increase in the maximum value of the relative force. By increasing the stiffness as well, as for a very small truss' rod pitch about the horizontal axis $\left(5-10^{\circ}\right)$, it is possible to get no negative values of the relative force on the graph, as indicated 


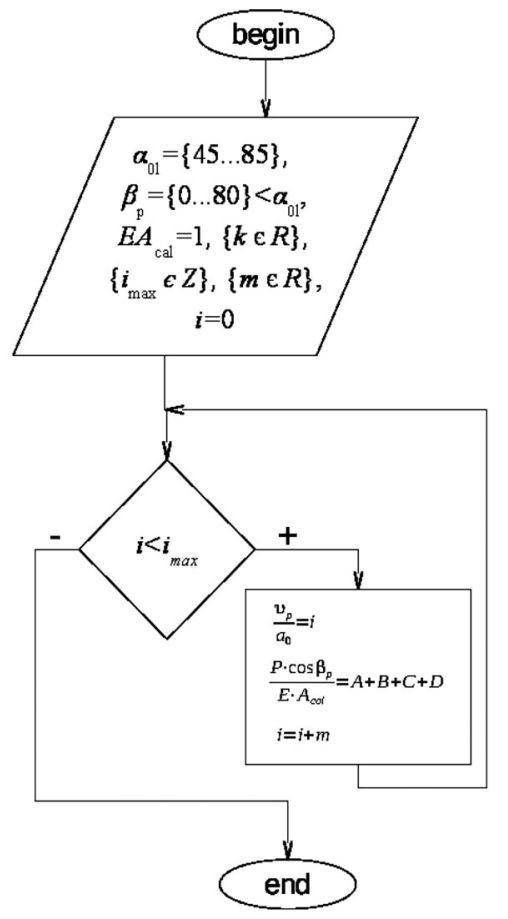

Figure 2: Algorithm of numerical research of joint buckling of von Mises trusses where $\alpha_{01}$ - initial rod pitch about the vertical axis; $a_{0}-$ half of truss span; $\beta_{\mathrm{p}}$ - force pitch at the apex joint about the vertical axis; $E A_{\text {cal }}$ - rod's compressive stiffness; $k_{v}$ - elastic support stiffness parameter for the apex joint; $i$ - number of iterations during the study inserted in options A, B, C, D (1) instead of vertical joint displacement value $v_{\mathrm{p}} / \mathrm{a}_{0} ; m$ - iteration step (dependence graph scale); $P^{*} \cos \beta_{\mathrm{p}} / E A_{\text {cal }}$ - relative force at the apex joint or active load value; $v_{\mathrm{p}} / a_{0}$ - relative vertical displacement or vertical displacement indicator

in Figures 3b and 3c. With a further increase in elasticity, the dependence becomes closer to linear (Figure 3c).

In the case of the classic Mises truss, dependence between the initial truss' rod pitch and the maximum value of the relative force at the apex joint assumes the shape of a downward curve. In the case of the sloped load of the apex joint, we considered a force pitch of $10-80^{\circ}$ about the vertical axis, provided that it is always smaller than the initial rod pitch.
With the algorithm (Figure 2), we obtained the dependencies between the maximum force value at the apex joint and the initial rod's slope (Figure 4).

It is possible to describe the obtained dependence (Figure 4a) with the following polynomial of the third degree:

$P_{\text {max }}^{\text {rel }}=\frac{P \cdot \cos \beta_{\mathrm{p}}}{E \cdot A_{\text {cal }}}=K_{1} \cdot \alpha_{0 l}^{3}+K_{2} \cdot \alpha_{0 l}^{2}+K_{3} \cdot \alpha_{0 l}+K_{4}$

where $\alpha_{01}$ is the initial rod pitch, while coefficients $K_{1}$, $K_{2}, K_{3}, K_{4}$ for different force-pitch $\beta_{\mathrm{p}}$ values are given in Table 1.

Table 1: Coefficients from Equation (2)

\begin{tabular}{|c|c|c|c|c|}
\hline$\beta_{\mathrm{p}}$ & $K_{1}$ & $K_{2}$ & $K_{3}$ & $K_{4}$ \\
\hline 0 & $-2.09 \mathrm{e}-06$ & $5.62 \mathrm{e}-04$ & $-5.04 \mathrm{e}-02$ & 1.51 \\
\hline 10 & $-2.14 \mathrm{e}-06$ & $5.76 \mathrm{e}-04$ & $-5.16 \mathrm{e}-02$ & 1.54 \\
\hline 20 & $-2.38 \mathrm{e}-06$ & $6.34 \mathrm{e}-04$ & $-5.65 \mathrm{e}-02$ & 1.68 \\
\hline 30 & $-3.15 \mathrm{e}-06$ & $8.20 \mathrm{e}-04$ & $-7.13 \mathrm{e}-02$ & 2.08 \\
\hline 40 & $-6.69 \mathrm{e}-06$ & $1.63 \mathrm{e}-03$ & $-1.33 \mathrm{e}-01$ & 3.63 \\
\hline
\end{tabular}

Dependence of the relative displacement values, at which the system starts losing the stability of the initial rod pitch, is shown in Figure 5.

It is possible to describe the obtained dependence (Figure 5) with the following polynomial of the third degree:

$$
v_{\text {rel }}=\frac{v_{\mathrm{p}}}{a_{0}}=K_{5} \cdot \alpha_{0 l}^{3}+K_{6} \cdot \alpha_{0 l}^{2}+K_{7} \cdot \alpha_{0 l}+K_{8}
$$

where $\alpha_{01}-$ the initial rod pitch; coefficients $K_{1} \ldots K_{5}$ for different force pitch $\beta_{\mathrm{p}}$ values are shown in Table 2.

Table 2: Coefficients of Equation (3)

\begin{tabular}{|c|c|c|c|c|}
\hline$\beta_{\mathrm{p}}$ & $K_{5}$ & $K_{6}$ & $K_{7}$ & $K_{8}$ \\
\hline 0 & $-2.79 \mathrm{e}-06$ & $6.88 \mathrm{e}-04$ & $-6.42 \mathrm{e}-02$ & 2.24 \\
\hline 10 & $-2.92 \mathrm{e}-06$ & $7.19 \mathrm{e}-04$ & $-6.68 \mathrm{e}-02$ & 2.31 \\
\hline 20 & $-3.45 \mathrm{e}-06$ & $8.45 \mathrm{e}-04$ & $-7.71 \mathrm{e}-02$ & 2.61 \\
\hline 30 & $-4.92 \mathrm{e}-06$ & $1.19 \mathrm{e}-03$ & $-1.04 \mathrm{e}-01$ & 3.35 \\
\hline 40 & $-8.38 \mathrm{e}-06$ & $1.98 \mathrm{e}-03$ & $-1.65 \mathrm{e}-01$ & 4.96 \\
\hline
\end{tabular}
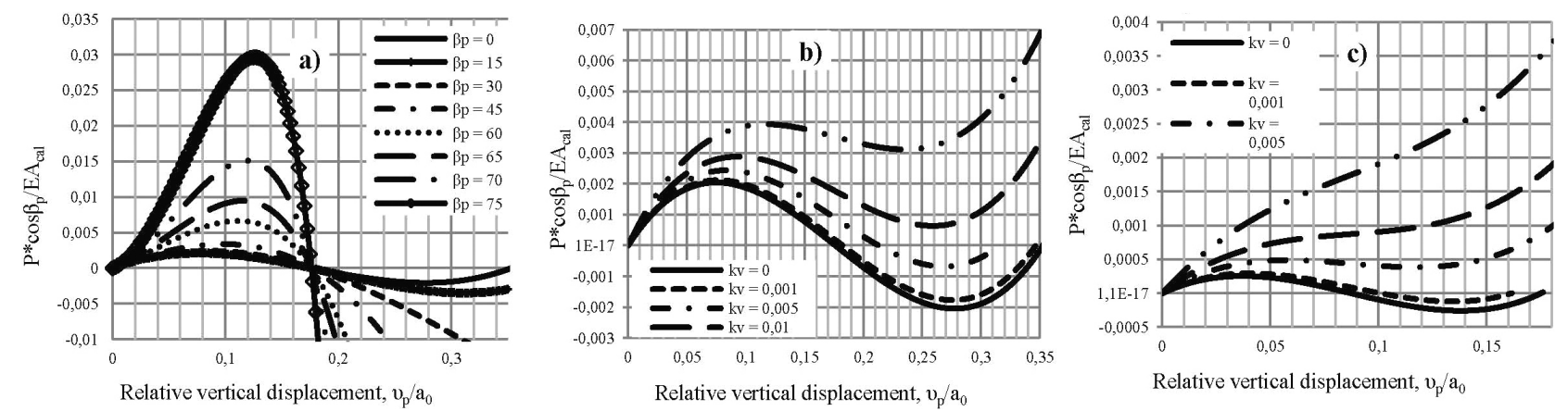

Figure 3: Dependence of the relative force at the apex joint $P^{*} \cos \beta_{\mathrm{p}} / E A_{\mathrm{cal}}$ on the relative vertical displacement of joint $v_{\mathrm{p}} / \alpha_{01}$; a) $\alpha_{01}=80^{\circ} ; \beta_{\mathrm{p}}=0$; $k_{v}=0$; b) $\beta_{\mathrm{p}}=0 ; k_{v}$ in a range of $(0 \ldots .0 .02)$; c) $\alpha_{01}=85^{\circ} ; \beta_{\mathrm{p}}=0 ; k_{v}$ in a range of $(0 \ldots .02)$ where $\alpha_{01}-$ initial rod pitch about the vertical axis; $a_{0}-$ half of truss span; $\beta_{\mathrm{p}}$ - force pitch at the apex joint about the vertical axis, $k_{v}$ - elastic support stiffness parameter for the apex joint 

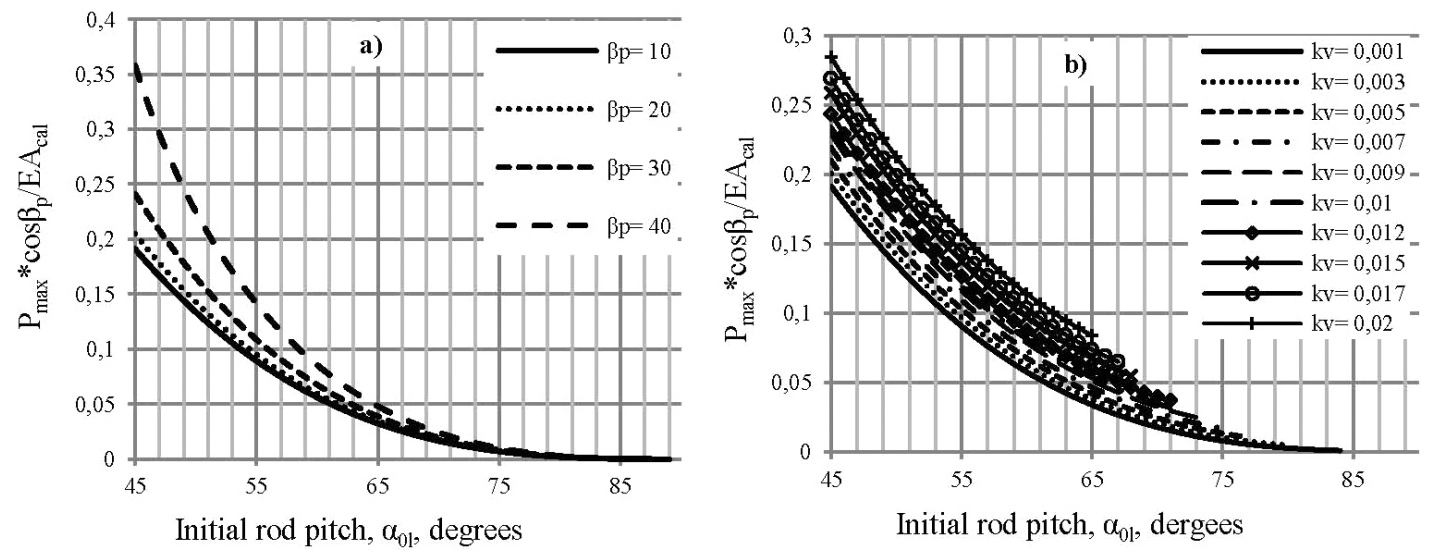

Figure 4: Dependence of the maximum relative force at the apex joint $P_{\max }{ }^{*} \cos \beta_{\mathrm{p}} / E A_{\mathrm{cal}}$ on the initial rod pitch $\alpha_{01}$; a) $\beta_{\mathrm{p}}<\alpha_{01}$; $k_{v}=0$; b) $\beta_{\mathrm{p}}=0$; $a_{0}=9 \mathrm{~m} ; k_{v}$ in a range of $(0.001 \ldots 0.2)$ where $\alpha_{01}$ - initial rod pitch about the vertical axis; $a_{0}-$ half of truss span; $\beta_{\mathrm{p}}-$ force pitch at the apex joint about the vertical axis, $k_{v}$ - elastic support stiffness parameter for the apex joint



Figure 5: Dependencies of the relative vertical displacements of the truss' apex joint $v_{\mathrm{p}} / a_{0}$, at which the joint buckling appears, on the initial truss' rod pitch $\alpha_{01}$ for different force pitch $\beta_{\mathrm{p}}$ values where $\alpha_{01}$ is the initial rod pitch about the vertical axis; $a_{0}$ is the half of truss $\operatorname{span} ; \beta_{\mathrm{p}}$ is the force pitch at the apex joint about the vertical axis

In the case when the apex joint had elements providing a certain joint stiffness (elastic support), we considered the cases, in which the stiffness value was within $(0.001 \ldots 0.2)$ for a truss span of $18 \mathrm{~m}$.

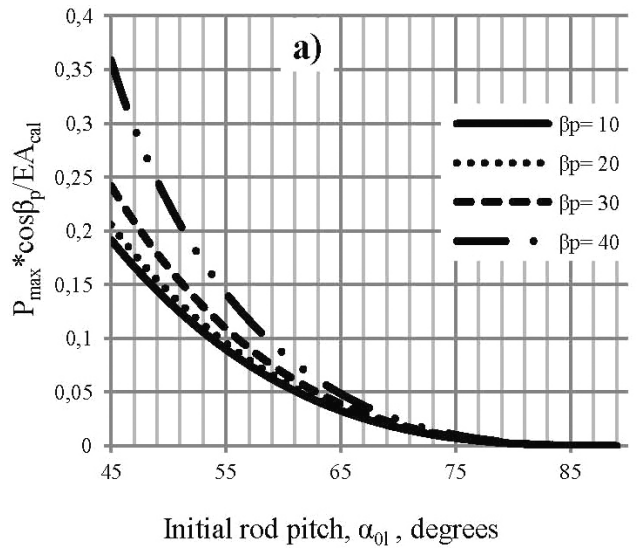

In the case of an elastic-support inception into the apex joint at a large initial rod pitch about the vertical axis, we do not see the maximum relative-force values. This is due to the lack of a pronounced extremum on the graph of the relative-force dependency at the apex joint on the relative apex-joint displacement (Figure 3c).

In the mixed case of a sloped load in the presence of an elastic support at the apex joint, we considered a system with elastic-support stiffness parameters within (0.001: 0.02) for the force pitch at the apex joint in a range of $10-40^{\circ}$ about the vertical axis for the truss span of $18 \mathrm{~m}$.

Averaging the maximum relative force in the presence of the elastic support at the apex joint becomes more complicated due to the need to consider not only the stiffness of the elastic support, but also the truss span and rod's stiffness for each case of the calculations. According to the above numerical-algorithm studies (Figure 2), the maximum relative force at the apex joint in the presence of the elastic support can be defined as the sum of the maximum relative-force values without the elastic support, considering only components $B, C$,

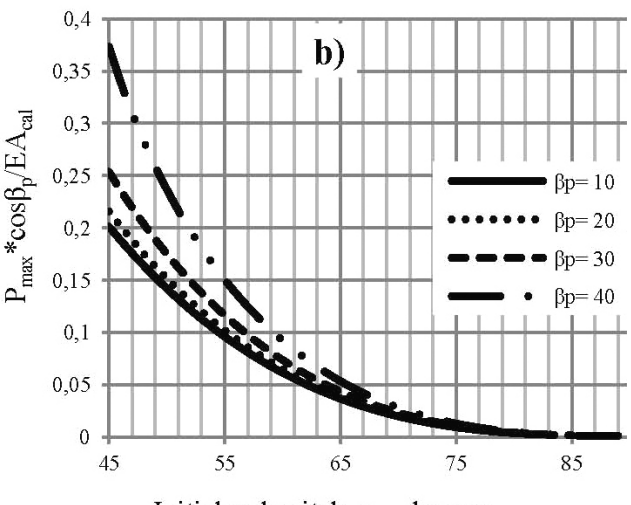

Initial rods pitch, $\alpha_{01}$, degrees

Figure 6: Dependence of the maximum relative force at the apex joint $P_{\max }{ }^{*} \cos \beta_{\mathrm{p}} / E A_{\mathrm{cal}}$ on the initial rod slope $\alpha_{01}$, with different values of force pitch $\beta_{\mathrm{p}}$, and $a_{0}=9 \mathrm{~m}$; a) $k_{v}=0.001$; b) $k_{v}=0.02$ where $a_{0}-$ half of the truss span; $\beta_{\mathrm{p}}-$ the force pitch at the apex joint about the vertical axis, $k_{v}-$ elastic support stiffness parameter for the apex joint 
$D$, while considering the $A$ component separately, see Equation (1). Hence, we get a generalized equation to determine the maximum relative force:

$$
\left[P_{\max }^{\mathrm{rel}}\right]_{k_{v}}=\frac{P_{\mathrm{max}} \cdot \cos \beta_{\mathrm{p}}}{E \cdot A_{\mathrm{cal}}}=P_{\mathrm{max}}^{\mathrm{rel}}+v_{\mathrm{rel}} \frac{a_{0} \cdot k_{v}}{E \cdot A_{\mathrm{cal}}}
$$

Where $P_{\max }^{\text {rel }}$ - the maximum relative force obtained from Equation (2); $v_{\text {rel }}$ - relative vertical displacement of the apex joint, at which the system starts losing its stability, calculated with Equation (3); $a_{0}$ - half of the von Mises truss span; $k_{v}$ - parameter of the rigidity of the elastic support at the ridge node; $E$ - the elasticity modulus; $A_{\text {cal }}$ - the estimated cross-section of truss' rods; $\beta_{\mathrm{p}}$ - the force pitch about the vertical axis.

Below is the search algorithm of the maximum relative force in the presence of an elastic support at the apex joint:

1. We can use Table 1 to determine the maximum relative force at the apex joint;

2. We can use Table 2 to determine the appropriate relative vertical displacement of the apex joint;

3. The values found, as well as the truss' span and rods' stiffness should be inserted into Equation (4), from which we get the maximum relative force considering the presence of the elastic support at the apex joint. The results of this algorithm are shown in Figure 6.

\section{CONCLUSIONS}

1. We found dependencies of the maximum joint-load values, at which the von Mises truss starts losing its stability, on the initial truss' rod pinch, which in turn allows the designer to evaluate the carrying capacity of dome structures with known geometrical parameters.

2. We obtained general expressions to determine the maximum relative-force values for different design cases, which make it possible to evaluate the carrying capacity of a dome with an elastic support at the apex joint and under a sloped load.

3. The proposed method allows us to check the stiffness of a complex system at the earlier stages of design.

4. The proposed study is acceptable for use when considering the elastic buckling of von Mises trusses with the elements with a pitch characteristic for dome coverings, provided that the local stiffness is ensured for each element.

\section{REFERENCES}

${ }^{1}$ S. I. Bilyk, Rational shape of the geometric layout of a channel frame with sloped cornice elements around the functional volume, Applied geometry and engineering graphics, Interdepartmental scientific collection, KNUBA, Kyiv, 2004, 74, 228-235

${ }^{2}$ Z. P. Bazant, L. L. Cedolin, J. W. Hutchinson, Stability of Structures: Elastic, Inelastic, Fracture, and Damage Theories, ASME, J. Appl. Mech, 60 (1993) 2, 567-568, doi:10.1115/1.2900839

${ }^{3}$ R. Casciaro, Nonlinear analysis: main problems and solution methodologies, Universit'a della Calabria, Italy, https://www.researchgate. net/profile/Raffaele_Casciaro/publication/267936881_Nonlinear_ana lysis_main_problems_and_solution_methodologies/links/56095b030 8ae576ce63e1e63.pdf, 23.11.2016

${ }^{4}$ R. W. Ogden, Non-Linear Elastic Deformation, Engineering Analysis, 1 (1984) 2, 119, doi:10.1016/0264-682X(84)90061-3

${ }^{5}$ Frederick Stanley Doten, Methods of nonlinear structural analysis, University of Arizona, 1972, http://hdl.handle.net/10150/318793, 23.11.2016

${ }^{6}$ R. V. Mises, Über die Stabilitätsprobleme der Elastizitätstheorie, Z. Angew. Math. Mech., 3 (1923), 406-422, doi:10.1002/zamm. 19230030602

${ }^{7}$ Y. G. Panovko, I. I. Gubanov, Stability and oscillations of elastic systems, Moskow, Nauka, 1987, 352

${ }^{8}$ Marcelo Greco, Carlos Eduardo Rodrigues Vicente, Analytical solutions for geometrically nonlinear trusses, Revista Escola de Minas, 62 (2009) 2, 205-214, doi:10.1590/S0370-44672009000200012

${ }^{9}$ N. G. Bondar, Stability and oscillations of elastic systems in modern technology, Kiev, High School, 1987, 210

${ }^{10}$ G. R. Cook, E. Simiu, Periodic and Chaotic Oscillations of Modified Stoker Column, Journal of Engineering Mechanics, 117 (1991) 9, 2049-2064, doi:10.1061/(ASCE)0733-9399(1991)117:9(2049)

${ }^{11}$ Y. V. Mikhlin: Nonlinear normal vibration modes and their applications, Proceedings of the 9th Brazilian Conference on Dynamics, Control and their Applications Serra Negra, (2010), 151-171, http://www.sbmac.org.br/dincon/trabalhos/PDF/invited/68092.pdf, 23.11.2016

${ }^{12} \mathrm{~V}$. Feodosiev, Theory of strength of materials, chosen problems and questions, Moskow, Nauka, 1967, 376, https://dwg.ru/lib/2151

${ }^{13}$ W. Nachbar, N. C. Huang: Dynamic snap-through of a simple viscoelastic truss, Q. Appl. Math., 25 (1967), 65-82, https://www. researchgate.net/publication/268490270_Dynamic_snap-through_of_ a_simple_viscoelastic_truss, 23.11.2016

${ }^{14}$ M. A. Crisfield, Non-Linear Finite Element Analysis of Solids and Structures, J. Eng. Mech., 1 (1993) 7, 1504-1505, doi:10.1061/ (ASCE)0733-9399(1993)119:7(1504)

${ }^{15}$ D. P. Mondkar, G. H. Powell, Finite element analysis of non-linear static and dynamic response, Int. J. Numer. Meth. Engng., 11 (1977), 499-520, doi:10.1002/nme.1620110309

${ }^{16} \mathrm{H}$. Thai, S. Kim, Nonlinear inelastic time-history analysis of truss structures, Journal of Constructional Steel Research, 67 (2011) 12, 1966-1972, doi:10.1016/j.jcsr.2011.06.015

${ }^{17}$ S. I. Bilyk, V. G. Tonkacheiev, Impact of direction of joint load on Mises' truss buckling in presence of elastic supports as in case of steel ribbed-ring dome, Building, materials, mechanic engineering, Collection of scientific papers, Dnipropetrovs'k, PSAES, 82 (2015), 44-49

${ }^{18}$ V. G. Karmanov, Mathematical Programming, 5th ed., Moskow, FIZMATLIT, 2004, 264

${ }^{19}$ L. Driemeier, S. P. B. Proença, M. Alves, A contribution to the numerical nonlinear analysis of three-dimensional truss systems considering large strains, damage and plasticity, Communications in Nonlinear Science and Numerical Simulation, 10 (2005), 515-535 doi:10.1016/j.cnsns.2003.12.002 